\title{
Prediction of the meteorologic and hydrologic data by a comprehensive downscaling method under the climate change background: A case study of the Huangshui Basin
}

Han Wang ${ }^{1}$, Zhenghui $\mathrm{Fu}^{1}$, Wentao $\mathrm{Lu}^{2}$, Shuhang Wang ${ }^{3}$, Huaicheng Guo ${ }^{4}$, and Shulan Wang $^{1}$

${ }^{1}$ Chinese Research Academy of Environmental Sciences

${ }^{2}$ Chinese Academy for Environmental Planning

${ }^{3}$ Chinese Research Academy of Environmental Science

${ }^{4}$ Peking University

June 18, 2020

\section{Hosted file}

Main document.docx available at https://authorea.com/users/334749/articles/460674-predictionof-the-meteorologic-and-hydrologic-data-by-a-comprehensive-downscaling-method-under-theclimate-change-background-a-case-study-of-the-huangshui-basin

\section{Hosted file}

Table.docx available at https://authorea.com/users/334749/articles/460674-prediction-ofthe-meteorologic-and-hydrologic-data-by-a-comprehensive-downscaling-method-under-theclimate-change-background-a-case-study-of-the-huangshui-basin

\section{Hosted file}

Figure.docx available at https://authorea.com/users/334749/articles/460674-prediction-ofthe-meteorologic-and-hydrologic-data-by-a-comprehensive-downscaling-method-under-theclimate-change-background-a-case-study-of-the-huangshui-basin 